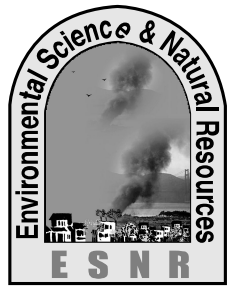

J. Environ. Sci. \& Natural Resources, 5(1): 117 - 120, 2012

ISSN 1999-7361

\title{
Effect of Seed-borne Fungi on the Germinating Seeds and their Bio-control in Maize
}

\author{
M. Debnath, A. Sultana and A. Q. M. B. Rashid \\ Seed Pathology Center, Bangladesh Agricultural University, Mymensingh
}

\begin{abstract}
An experiment was conducted in Seed Pathology Center, Bangladesh Agricultural University, Mymensingh to determine the efficacy of biocontrol means (BAU-Biofungicide, Garlic extract and Neem extract) in controlling seedborne fungal diseases of maize (Zea mays). In laboratory experiment, the seeds of maize cultivars cv. Badsha-1, Khai Bhutta, Bornali, Mohor, BARI Bhutta- 5 and BARI Bhutta- 6 were tested by blotter method. The identified fungi associated with the seeds were A. niger, A. flavus, Fusarium sp., P. oxalicum, $C$. lunata and $R$. stolonifer. The seed samples were treated with BAU-Biofungicide@ 2.5\% of seed weight, neem extract@ 1:2 w/v and 1:3 w/v and garlic extract @ 1:2 w/v and 1:3 w/v to control the seed-borne pathogens. The effective results were recorded as regards to the highest germination $(84.5 \%)$ reflected the lowest disease incidence $(4.0 \%)$ recorded in BAUBiofungicide treated seeds followed by other treatment.
\end{abstract}

Key words: BAU-Biofungicide, Germination, Seed borne pathogen

\section{Introduction}

Maize (Zea mays L.) is one of the most important cereal crops in the world and ranks third next to wheat and rice (Aldrich et al., 1975). In Bangladesh, it has a good potential as a cereal crop due to its low cost of production, wide adaptability and diversified use. There are many factors involved in yield loss in which diseases play a significant role. Maize suffers from 28 diseases in seedling stage (Bari and Alam, 2004) in which 11 are seedborne in nature (Fakir, 2001). Among the diseases, seed rot (F. moniliforme, F. oxysporum, Penicillium spp.), seedling blight (Aspergillus spp., Penicillium spp.), Bipolaris leaf spot (B. maydis), Curvularia leaf spot (C. lunata) etc are important ones. Chemical control of seed borne diseases is rather difficult to achieve a reasonably good control. Due to its hazardous environmental effect, the researchers have given attention on biocontrol. Therefore the present piece of work has undertaken with the filling the objectives.

\section{Materials and Methods}

\section{Test materials}

Six maize cultivars collected from BADC of maize growing areas such as Mymensingh, Dinajpur, Madupur, Rangpur and Gazipur. The varieties were Badsha- 1, Khai Bhutta, Bornali, Mohor, BARI Bhutta- 5 and BARI Bhutta- 6. The seed samples preserved and tested in Seed Pathology Center, Bangladesh Agricultural University, Mymensingh during 2010-11.

\section{Seed health test}

Seed health test was done by standard blotter method (ISTA, 2001). The seedborne fungal pathogen associated with seeds was observed by stereobinocular microscope following the key of Mathur and Kongsdal (1994).

\section{Collection of bio-control agents}

BAU-Biofungicide (Trichoderma based preparation Hossain, 2011) was collected from the Diseases Resistance Laboratory; Garlic and neem extracts were prepared in the Plant Disease Clinic, Department of Plant Pathology, BAU, Mymensingh.

\section{Seed treatment}

One hundred seeds of six varieties were treated with each of BAU-Biofungicide @ 2.5\% of seed weight, neem extract@1:2w/v, 1:3w/v and garlic extract@ 1:2 w/v and 1:3 w/v (Rahman et al., 1999) to control the seed borne pathogen.

\section{Experimental design and treatments}

The experiment was designed following CRD having four replications and six treatments, where $\mathrm{T}_{1}=$ Seed treatment with garlic extract @ 1:2 w/v $\mathrm{T}_{2}=$ Seed treatment with garlic extract @ 1:3 w/v $\mathrm{T}_{3}=$ Seed treatment with neem extract @ 1:2 w/v 
$\mathrm{T}_{4}=$ Seed treatment with neem extract @ 1:3 w/v

$\mathrm{T}_{5}=$ Seed treatment with BAU-Biofungicide $(2.5 \%$ of seed weight)

$\mathrm{T}_{0}=$ Control

\section{Results and Discussion}

\section{Prevalence of seedborne fungi}

Fungi associated with the maize seeds recorded through blotter method are presented in Table 1. The prevalence of $A$. niger, A. flavus, Fusarium spp., $P$. oxalicum, $C$. lunata and $R$. stolonifer were varied significantly with respect to variety. Statistically the highest prevalence of $A$. niger was recorded in Khai Bhutta $(23.50 \%)$ followed the variety of Mohor
(21.00\%), A. flavus was recorded in Badsha-1 $(21.50 \%)$ followed by the variety of Bornali (19.50\%), Fusarium sp. was recorded in Mohor $(13.75 \%)$ followed by the variety of Bornali (12.50\%), P. oxalicum was recorded in Badsha- 1 $(12.25 \%)$ followed the variety of Khai Bhutta $(9.50 \%), C$. lunata was recorded in Khai Bhutta $(6.25 \%)$ followed by the variety of Mohor $(5.75 \%)$, $R$. stolonifer was recorded in Khai Bhutta (12.50\%) followed by the variety of Mohor $(11.50 \%)$. The least but similar prevalence of the fungi was recorded in rest of the varieties tested. In agreement with the present findings Fakir (2001), Bari and Alam (2004) also reported the same.

Table 1. Prevalence of fungi associated with the maize seeds (blotter method)

\begin{tabular}{|l|l|l|l|l|l|l|}
\hline \multirow{2}{*}{ Variety } & \multicolumn{5}{|c|}{ Prevalence of fungi (\%) } \\
& $\begin{array}{c}\text { Aspergillus } \\
\text { niger }\end{array}$ & $\begin{array}{c}\text { Aspergillus } \\
\text { flavus }\end{array}$ & $\begin{array}{c}\text { Fusarium } \\
\text { sp. }\end{array}$ & $\begin{array}{c}\text { Penicillium } \\
\text { oxalicum }\end{array}$ & $\begin{array}{c}\text { Curvularia } \\
\text { lunata }\end{array}$ & $\begin{array}{c}\text { Rhizopus } \\
\text { stolonifer }\end{array}$ \\
\hline Badsha-1 & $18.75 \mathrm{c}$ & $21.50 \mathrm{a}$ & $11.50 \mathrm{c}$ & $12.25 \mathrm{a}$ & $4.50 \mathrm{bc}$ & $10.00 \mathrm{~cd}$ \\
\hline Khai Bhutta & $23.50 \mathrm{a}$ & $13.50 \mathrm{~d}$ & $11.25 \mathrm{~cd}$ & $9.50 \mathrm{~b}$ & $6.25 \mathrm{a}$ & $12.50 \mathrm{a}$ \\
\hline Mohor & $21.00 \mathrm{~b}$ & $18.25 \mathrm{c}$ & $13.75 \mathrm{a}$ & $7.75 \mathrm{~cd}$ & $5.75 \mathrm{a}$ & $11.50 \mathrm{ab}$ \\
\hline Bornali & $18.25 \mathrm{c}$ & $19.50 \mathrm{~b}$ & $12.50 \mathrm{~b}$ & $9.00 \mathrm{~b}$ & $3.50 \mathrm{c}$ & $11.00 \mathrm{bc}$ \\
\hline BARI Bhutta- 5 & $18.50 \mathrm{c}$ & $11.50 \mathrm{e}$ & $10.50 \mathrm{~d}$ & $8.75 \mathrm{bc}$ & $5.25 \mathrm{ab}$ & $9.50 \mathrm{de}$ \\
\hline BARI Bhutta- 6 & $19.25 \mathrm{c}$ & $9.00 \mathrm{f}$ & $11.50 \mathrm{c}$ & $7.00 \mathrm{~d}$ & $3.50 \mathrm{c}$ & $8.75 \mathrm{e}$ \\
\hline
\end{tabular}

Effect of the fungi on germinating seeds

Effect of the fungi on germination of maize seeds of six cultivars is presented in the Figure 1. The effect significantly differed from cultivar to cultivar. Significantly, the highest germination failure was recorded in Khai Bhutta $(29.50 \%)$ in which maximum prevalence of various fungi were recorded. The result was followed by other varieties. The highest effect of the fungal prevalence reflected the lowest germination as recorded in which significantly maximum prevalence were recorded the fungi species Aspergillus niger, Curvularia lunata, Rhizopus stolonifer and Penicillium oxalicum. The present findings of the seed borne fungal organisms were in agreement with the information of seed borne nature of the pathogen reported by Marley and Gbenga (2004). 


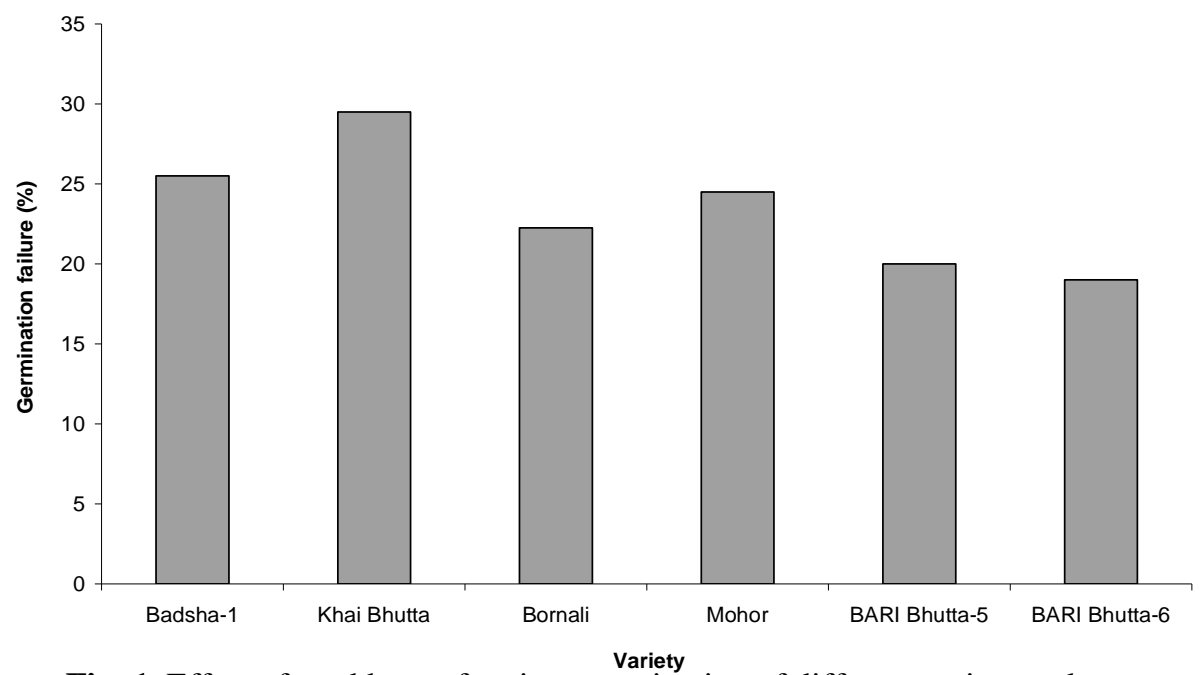

Fig. 1. Effect of seed borne fungi on germination of different maize seed

Effect of seed treatment by different plant extracts and BAU-Biofungicide on germination of maize seeds

The effect of garlic extract $(1: 2,1: 3)$, neem extract $(1: 2,1: 3)$ and BAU-Biofungicide $(2.5 \%$ of seed weight) on the seed borne pathogen associated with germinating seeds Khai Bhutta is presented in Figure 2. Seed treatment by plant extracts and BAUBiofungicide showed great impact on germination and reducing the disease incidence.

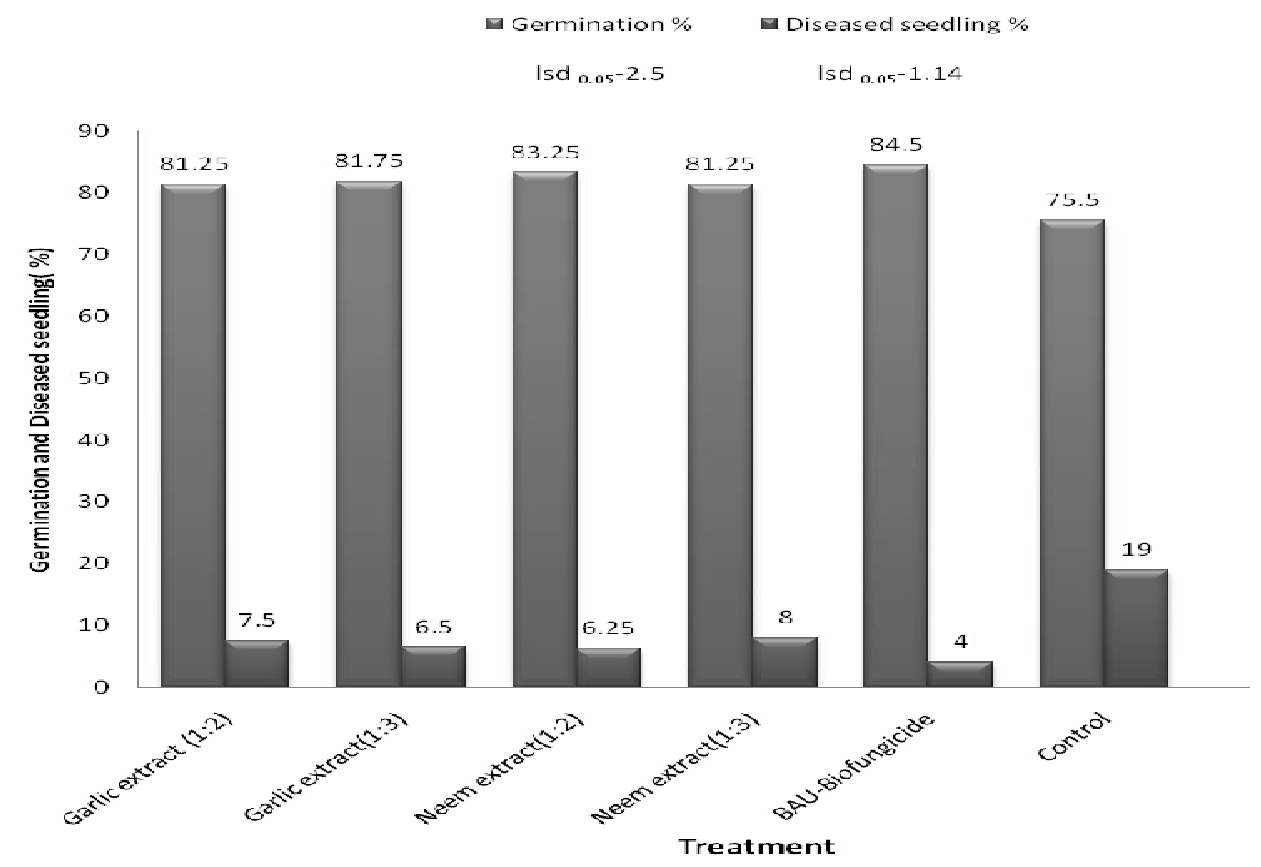

Fig. 2. Effect of plant extracts and BAU-Biofungicide on germination of the maize seed (cv. Khai Bhutta) 
It is revealed from the Figure 2 that significantly the highest germination $(84.5 \%)$ reflected the lowest disease incidence recorded in the seeds treated by BAU-Biofungicide@ $2.5 \%$ followed by the other treatments. The least germination $(75.5 \%)$ and the highest disease incidence $(10 \%)$ were recorded in control. Therefore, the result of the present findings is agreed with the results of other workers Rahman (2006) and Awal (2005).

\section{Conclusions}

The garlic extract, neem extract and the BAUBiofugicide showed the significant result in controlling seedborne fungal pathogen in maize. Among them, the BAU-Biofugicide has the strong potentiality for treating seeds of maize in controlling seed and seedling diseases. So, the seed treatment by BAU-Biofugicide should be widely explored to the country.

\section{References}

Aldrich, S. R.; Scott, W. O. and Leng E. R. 1975. Modern corn production. $2^{\text {nd }}$ edition. United States of America. pp. 1-5.

Awal, K. J. M. 2005. Determination of effective dose of garlic tablet and its durability in controlling seedling disease of eggplant. MS. thesis submitted to the Department of Plant Pathology, Bangladesh Agricultural University, Mymensingh . 1-88pp.
Bari, M. A. and Alam, M. S. 2004. Major diseases of wheat and maize and their control. A Bengali Booklet published from the Division of Plant Pathology, BARI, Joydebpur, Gazipur 2: 12-16.

Fakir, G. A. 2001. List of seed borne diseases of important crops occurring in Bangladesh. Seed Pathol. Lab., Dept. Pl. Pathol., Bangladesh Agricultural University, Mymensingh. 9p.

Hossain, I. 2011. BAU-Biofungicide: Unique Ecofriendly Means and New Dimension of Plant Disease Control in Bangladesh. Department of Plant Pathology, Bangladesh Agricultural University, Mymensingh.

ISTA (International Seed Testing Association). 2001. International Rules for Seed Testing. Rules Amendments. Seed Sci. and Tech. 29 (2): 1-127.

Marley, P. S. and Gbenga, O. 2004. Fungicide control oif Stenocarpella maydis in the Nigerian Savanna. Archives of Phytopathology and Plant Protection. 37 (1): 19-28.

Mathur, S. B. and Kongsdal, O. 1994. Seed mycology. Description and Illustrations of fungi. DGISP for Developing, Denmark, $1^{\text {st }}$ edn.

Rahman, M. M. 2006. Biological control of seedling diseases of papaya,Water melon and melon. MS. Thesis submitted to the Department of Plant Pathology, Bangladesh Agricultural University, Mymensingh.

Rahman, G. M. M., Islam, M. R. and Wadud, M. A. 1999. Seed treatment with plant extracts and hot water, potential biophysical method of controlling seed-borne infection of wheat. Bangladesh $J$. Train. Dev. 12 (1-2): 185-190. 